\title{
Cause and Condition in Time Clauses
}

\author{
Erjon Agolli \\ University of Tirana, Faculty of Foreign Languages, \\ English Department \\ agollierjon@yahoo.com
}

\section{Doi:10.5901/ajis.2013.v2n8p405}

\begin{abstract}
Time clauses can express a wide range of semantic relations other than time. This is due to the fact that the conjunctions alone are not responsible for the temporal meaning of the complex sentence with time clauses, on the contrary; other factors such as the extralinguistic context, the internal dynamics of the actions in the main and subordinate clause, and the meanings of predicates also influence the overall interpretation of the sentence. Because of the overlapping of temporal meaning with other shades of meaning, time clauses can present semantic implications of cause, condition, result, purpose, concession, reason, contrast, etc. These shades of meaning sometimes add up to the temporal meaning, coexisting with it, and sometimes they totally rule out temporal meaning, altering the semantic content of the conjunction itself. This paper aims at pointing out the variety of semantic relations expressed by time clauses in English and Albanian, as well as identifying the mechanisms responsible for the complete or partial overshadowing of temporal meaning in these clauses.
\end{abstract}

Keywords: semantic relations, shades of meaning, time clause, complex sentence

\section{Introduction}

Complex sentences with time clauses may imply other semantic relationships both in English and Albanian. However, it's important to note that the temporal meaning of the dependent clause is somehow eclipsed by the coexistence or overlapping of other shades of meaning that are created as a result of the semantic-structural interaction between the main clause and the dependent clause, as well as the context. The extent of the domination of these different semantic roles in the time conjunctions may vary, often leading to ambiguous interpretations of the clauses presented by these subordinators. For example, the turkey-cooking activities of her and her mother in (1e) below could be interpreted as taking place in the same time, temporal interpretation, or in the same way, comparative interpretation.

Thus, English grammarians Quirk et al. (1985), Huddleston et al. (2003), Puscasu et al. (2006) give a number of situations in which time clauses, in addition to temporal meaning, may introduce different meanings such as: cause, result, condition, concession, comparison, contrast, etc. Let's see these situations illustrated below:

(1)

a. I went to the bank, as I had run out of cash. (cause)

Shkova në bankë, pasi më kishin mbaruar paratë. (shkak)

b. Larry polished the table until you could see his face in it. (result)

Larri e pastroi tavolinën derisa mund të shihje fytyrën e tij në të. (rrjedhim)

c. I don't mind which of them wins it so long as Ferrari wins. (condition)

S'prish punë se kush do ta fitojë sa kohë që fiton Ferrari. (kusht)

d. She paid when she could have entered free. (concession)

Ajo pagoi kur mund të kishte hyrë falas. (lejim)

e. She cooks a turkey as her mother does. (comparison)

Ajo e gatuan gjelin e detit si e ëma. (krahasim)

Similarly, Albanian grammarians Totoni (2000), Akademia e Shkencave (2002), Çeliku et al. (2007), Totoni (2012) point out the fact that time clauses can be intertwined with other shades of meaning including: cause, condition, result, purpose, concession. According to Totoni (2000), "the main factor influencing the appearance of these meanings is the lexical completeness of the clauses and the meaning of predicates in the main clause, but there is also an influence from the outer context of the complex sentence. The overlapping meanings may take over and change the meaning of the conjunction itself, when characteristic elements of the sentence structure are altered". The following examples from the 
Albanian language present these meanings very clearly:

(2)

a. Skënderbeu s'mund të bënte dasmë pasi humbi Sfetigradin me Beratin. (shkak)

b. Pasi të derdhësh fjalët, nuk i mbledh dot. (kusht)

c. Dhanë e morën një copë herë, gjersa u bënë ujë në djersë. (rrjedhim)

d. Do t'u jap fitore të lehta, derisa t'i mashtroj e t'i shkëput nga pjesa tjetër e brigadës. (qëllim)

e. Zagari, edhe kur e ka thëllëzën ndër dhëmbë, shkon e ia dorëzon të zotit. (lejim)

Even though complex sentences with time clauses in English and Albanian represent a wide range of semantic nuances, below I will elaborate on time clauses indicating cause and condition, which are introduced by a variety of conjunctions, and briefly go through other shades of meaning encountered in time clauses.

\section{Causal implications}

Temporal location adjuncts are often accompanied by an implicature of causation (Huddleston et al. 2003). In the English language, causal relations may be indicated in the time clauses with the subordinators when, after, once, as, since:

(3)

a. When John attacked Bill the police arrested him.

(Kur Xhoni e sulmoi Billin policia e arrestoi.)

b. He felt better after he had a short nap.

(Ai u ndie më mirë pasi dremiti pak.)

c. He took his coat, since it was raining.

(Ai e mori pallton, që kur po binte shi.)

d. My family, once they saw the mood I was in, left me completely alone.

(Familja ime, sapo e pa se në ç'gjendje isha, më la plotësisht të qetë.)

e. The little boy was crying, as he had lost the key.

(Djali i vogël po qante, tek kishte humbur çelësin.)

When-clauses can be used to encode both temporal and causal relations simultaneously. The dependent clause in (3a) seems to have a considerable causal sense, providing the reason why John was arrested. The semantic interpretation becomes clear if we replace the time conjunction with the specialized conjunction of cause because. So, this example can be interpreted in this way: The police arrested John because he attacked Bill.

Schilder (1999) claims that "the after sentence may exhibit in addition to the temporal relation a causal relation between the situations described by the main and the temporal clause." Indeed, the after-clause in (3b) exhibits a causal relation between the filling-better situation and the having-a-nap situation.

The meaning of the subordinator since in (3c) proves to be ambiguous between the categories of time and cause because the action of taking the coat can be interpreted as starting at the moment when it was raining, or it can have a cause-effect relationship, with the rain causing the person to take the coat. Hamm (2001) points out that "many of the classical examples of ambiguity are really ambiguous only in context-free sentences, and (...) in most cases, our realworld knowledge and the discourse context situation offer, if not the interpretation, at least strong discursive orientations or clues". However, despite the lack of context, the causal interpretation is prevalent in (3c), as the meaning of the predicate and the past tense used in the main clause, as well as the presence of a comma separating the dependent clause from the matrix clause are not typical characteristics of temporal since-clauses.

The same interpretation applies for $(3 \mathrm{~d}, \mathrm{e})$, where the conjunctions once and as are interchangeable with the specialized conjunction of cause because. This way, the causal interpretation of these examples would be: "Because they saw the mood I was in, they left me completely alone"; and "The little boy was crying, because he had lost the key."

On the other hand, Çeliku et al. (2007) claims that causal relations in the Albanian language are expressed by clauses with time conjunctions such as kur, pasi, derisa, etc:

(4)

a. Nuk do ta kisha përmendur, pasi është një këngë jashtë shijes muzikore të kohës.

b. Por zgjedhja e vendit të betejës nuk varej nga Skënderbeu, derisa Ali Pasha mund të ndiqte edhe një rrugë tjetër për të hyrë në Shqipëri.

c. Na bëhet zemra mal, kur shohim rrugën e drejtë të Shqipërisë.

But we can also imply cause in clauses with the conjunctions si, tek, që kur, sapo (Akademia e Shkencave, 2002):

(5) 
a. Më pas, si e shikonte udhën të gjatë fort e pa mbarim, kthehej prapë me hap.

b. Dhe befas, sapo ra qetësia e plotë mbi fshat, u ndie rrjedha e lumit.

c. Që kur mori këtë udhë, vajza fatin e vet e siguroi.

According to Totoni (2012), the conjunctions pasi, and sapo, which usually occur with time clauses in postposition, present either an argument for the consequence expressed in the main clause (4a), or a signal for the change of the situations (5b). In both cases, the semantic change is conditioned by the lexical content of the clauses, and the interaction between them.

The temporal meaning in (4b) is almost completely lost since the conjunction derisa is used with a correlation of tenses that is not typical of time clauses. Thus, causal implications dominate, offering an explanation for the fact mentioned in the main clause.

With the conjunction kur, as in (4c), the causal meaning overlaps when the main clause describes an emotional state or reaction; in this case, the content of the subordinate clause is, in the same time, an argument for the consequence described in the main clause.

In addition, the conjunction tek indicates cause in complex sentences, the main clause of which contains a state of the subject, and the dependent clause does not only give a temporal orientation, but also a reason for the state of the subject in the main clause:

(6) Vesa ndriçonte mbi barin e gjelbër dhe atij i vinte keq tek shkelte mbi ato mijëra bula të vogla, si mijëra perla të shndritshme.

\section{Conditional implications}

Clauses with the conjunctions when, whenever, as/so long as, once, before can combine time with condition (Quirk et al.,1985). Let's study the following examples:

(7)

a. My heart leaps whenever / see you.

(Zemra më rreh fort sa herë të shoh.)

b. Go before I call the police! (Largohu para se të telefonoj policinë!)

c. I'm happy as long as my children are. (Jam i lumtur derisa fëmijët e mi janë të lumtur.)

d. Once I make up my mind to do something, I do it immediately.

(Sapo më mbushet mendja për të bërë diçka, e bëj menjëherë.)

In when-clauses, there is often a fusion of temporal notion with condition. Nevertheless, according to Declerck (1988), when and if are not necessarily equivalent, since there are hypothetical or counterfactual restrictive if-clauses, but no such when-clauses. When is always factual in meaning (i.e., it expresses realis). Compare:

(8)

a. People are happy if/when they have blue eyes.

(Njerëzit janë të lumtur nëse/kur kanë sy blu.)

b. People would be happier if/*when they had purple eyes.

(Njerëzit do të ishin më të lumtur nëse/*kur do të kishin sy vjollcë.)

Indeed, the use of when in (8b), which gives a hypothetical situation, makes the sentence ungrammatical, and the only possible conjunction here is if.

Qurik et al. (1985) highlights that "when the matrix clause is imperative, the sentence with a before-clause may imply a conditional relationship, as well as time". (7b) above can be interpreted as: If you don't go, I will call the police.

In order to better understand conditional relations in sentences $(7 c, d)$, the typical conjunctions of condition can come in handy. Thus, in (7c) the condition for his happiness is his children's happiness; and in (7d) the speaker means that he does something immediately if he makes up his mind.

In the Albanian language, the conditional meaning is added in time clauses with the conjunctions: kur, si, sapo, derisa and their synonymous conjunctions (Totoni, 2000):

(9)

a. Kur thahet përroi, gurët e nënujshëm dalin në diell.

b. Sapo të njihesh me të, bëhesh pjesë e mekanizmit të saj.

c. Nuk do t'ia japim dorën derisa të mos pranojë se ka qenë ai. 
Conditional meaning is most common in cases like (9a) above, where the presence of the present simple predicates in both clauses denotes a situation that is always true. However, in less frequent cases, conditional meaning is also added when the subordinate clause contains a hypothetical situation (Totoni, 2012):

(10) Kur nuk e kam këtu mbi kokë unë, zëre se nuk jeton fare.

The conjunction sapo is also used with conditional meaning, especially when the predicate of the dependent clause is in the subjunctive mood and denotes a speculation or assumption. See (9b) above.

Despite the presence of temporal relations existing between the main clause and the dependent clause, the conditional meaning sharply overlaps in (9c). At this point, the dependent clause with the conjunction derisa presents a hypothetical situation as a condition for the realization of the situation in the main clause.

\section{Other semantic relations}

In addition to cause and condition, complex sentences with time clauses may trigger other shades of meaning which, despite being less frequent, make up an interesting phenomenon giving way to a variety of semantic interpretations of time clauses.

\subsection{Result}

According to Quirk et al. (1985), before-clauses and until-clauses may imply result as well as time. The until-clause expresses the result of the activity described in the matrix clause:

(11)

a. I had to put my complaint in writing before they would take any action.

(Mu desh ta dorëzoja ankesën me shkrim para se të vepronin.)

b. She massaged her leg until it stopped hurting.

(Ajo i bëri masazh këmbës derisa i pushoi dhimbja.)

If we make a practical interpretation of the above cases, we can agree that the before-clause in (11a) contains a result situation (they took action) caused by my writing the complaint. In (11b), her pain stopped as a result of massaging her leg.

In Albanian, (Akademia e Shkencave, 2002) argues that the postposed dependent clause with the conjunctions gjersa, derisa, sa and with the predicate in the koha e kryer e thjeshtë (simple perfect tense) describes an action that is the result of the action in the matrix clause, and not really the time when the action in the matrix clause took place; the temporal relation is blended with implications of result:

(12)

a. Atje tej të thirrurat e Qamilit u rralluan, u bënë të thella e të pafuqishme, derisa në bodrum u bë heshtja e zakonshme.

b. Vazhdova t'i tregoja plakut edhe disa dokrra të tjera, gjersa u bë limon në fytyre.

c. Ajo lëvizi herë djathtas, herë majtas, sa u rrëzua.

In all these examples, the temporal relations are diminished somehow. So the meaning of result has taken over, and the action described in the dependent clause is the result of the action described in the main clause.

\subsection{Contrast}

Another semantic relation implied by time clauses is the contrastive relation, usually expressed by the connective while. In the contrastive interpretation of while, the notion "at the same time" is interpreted as at the same time of evaluation. Another feature that will effect the interpretation of a while-clause is a semantic one, viz. the presence of a contrast between the content of the two clauses in the sentence (Caenepeel, 1997):

(13) Gold mining issues were finally up just 0.1 per cent on the group index, while the oil sector ended down 0.35 per cent.

(Rezultatet e minierave të floririt u rritën me $0.1 \%$ në indeksin e grupit, $n$ dërsa sektori i naftës u mbyll me uljen $0.35 \%$.)

Indeed, in addition to the meaning of the conjunction, the contrastive relation is enabled by the interaction of the information presented in both clauses.

On the other hand, in Albanian contrast is expressed by the conjunction ndërsa, which presents two situations 
confronting each-other in the semantic point of view. The dependent clause is usually postposed:

(14)Ajo rrinte gjithnjë mbyllur në kullë ndërsa shoqet e saj gëzonin të ritë e tyre.

\subsection{Concession}

According to Hwang (2000), it is not common to find examples in which temporal and concessive meanings are conflated. Often the concessive part is not very obvious but detectable on close inspection. Concession can be expressed by the conjunctions when and while:

(15)

a. He won the race when all odds were against him.

(Ai e fitoi garën kur të gjitha shanset ishin kundër tij.)

b. While I don't want to make a fuss, I feel I must protest at your interference.

(Ndërkohë që nuk dua ta ekzagjeroj, e ndjej se duhet ta kundërshtoj ndërhyrjen tuaj.)

Interpreting these cases, we can say that although all odds were against him, he managed to win; and despite the fact that I don't want to make a fuss, I still feel I must protest at your interference.

In Albanian, concession is expressed by the conjunction kur if it is preceded by the particle edhe (Totoni, 2000):

(16) Zagari, edhe kur e ka thëllëzën ndër dhëmbë, shkon e ia dorëzon të zotit.

\section{Conclusions}

As e result of the interaction of the semantic contents of the main clause and the dependent clause, the temporal meaning in complex sentences with time clauses is combined with other shades of meaning, which in some cases give way to the appearance of different syntactic functions in these clauses. The main semantic implications triggered by such internal interactions include cause, condition, result, contrast, and concession.

Causal implications in English and Albanian are expressed respectively by the conjunctions when/ kur, after/ pasi, once/ sapo, as/ si (or tek), sincel që kur. Clauses introduced by these subordinators generally give an argument for the consequence described in the main clause. In many cases, the coexistence of temporal and causal meanings in these complex sentences enables an ambiguous interpretation which, however, can be decipherable due to the context, the lexical meaning of the predicates, the tense correlations, as well as the presence of a comma between the matrix clause and the dependent clause.

Furthermore, the conjunctions expressing conditional relations in English and Albanian time clauses include: when/ kur, as/so long as/ derisa, once/ sapo. These conditional relations combine with temporal relations especially when the dependent clause describes a hypothetical situation.

In addition to causal and conditional implications, which are more common, time conjunctions can be used to denote other semantic relations such as result, contrast, concession, etc. Thus, the meaning of result in English is rendered by before and until while the Albanian corresponding conjunctions are gjersa, derisa, and sa. Contrast is expressed by while, in English, and ndërsa, in Albanian. When-clauses and while-clauses, on the other hand, can also merge time with concession, whereas in Albanian the conjunction kur may add concessive meaning to the complex sentence if it is preceded by the particle edhe.

Of course, the main question that was addressed in this paper is how to disambiguate the content of such structures. One of the characteristics that is very useful in identifying and interpreting these semantic implications in the context is the interchangeability of these typical time conjunctions with specialized conjunctions of cause, condition, result, contrast and concession. This shows that the semantic content of the time conjunctions in these sentences is not only devalued but also altered into denoting a completely new shade of meaning and, in certain cases, the temporal meaning of these conjunctions may be stretched so far that the clauses introduced by them can no longer be classified as time clauses

\section{References}

Akademia e shkencave. (2002). Gramatika e gjuhës shqipe (sintaksa). Tiranë.

Caenepeel, M. (1997). Putting while in context. ESPRIT basic research project 6665, Dandelion. Edinburgh.

Çeliku, M., Karapinjalli, M., Stringa, R. ( 2007). Gramatika praktike e gjuhës shqipe, Tiranë: ILAR.

Decleck, R. (1988). Restrictive "when"-Clauses. Linguistics and Philosophy, Vol. 11, No. 2, pp. 131-168: Springer.

Hamm, A. (2001). Towards a discourse-related typology of ambiguity. Ranam. Special issue: Linguistic ambiguity. A. Hamm and P. 
Buccellato eds. 34: 29-41.

Huddleston, R., \& Pullum, G. K. (2003). The Cambridge Grammar of the English Language. Cambridge University Press.

Hwang, S. J. (2000). Multiple Functions of when-clauses in Discourse. LACUS Forum XXVI, pp. 455-466: University of Alberta.

Puscasu, G., Barco, P. M. \& Boro, E. S. (2006). On the Identification of Temporal Clauses. MICAl 2006: Advances in Artificial Intelligence. LNAI 4293, pp. 911-921. Berlin Heidelburg: Springer-Verlag.

Quirk, R., et al. (1972). A Grammar of Contemporary English. London and New York: Longman.

Schilder, F. (1999). Presupposition Triggered by Temporal Connectives. Proceedings of the TALN9 9 Workshop Theoretical Bases for Semantics and Pragmatics in NLP, Cargese.

Totoni, M. (2000). Fraza me nenrenditje. Tirana: SHBLU.

Totoni, M. (2012). Sintaksa e Gjuhës Shqipe (Fraza e Përbërë). Tirana: Arbëria. 